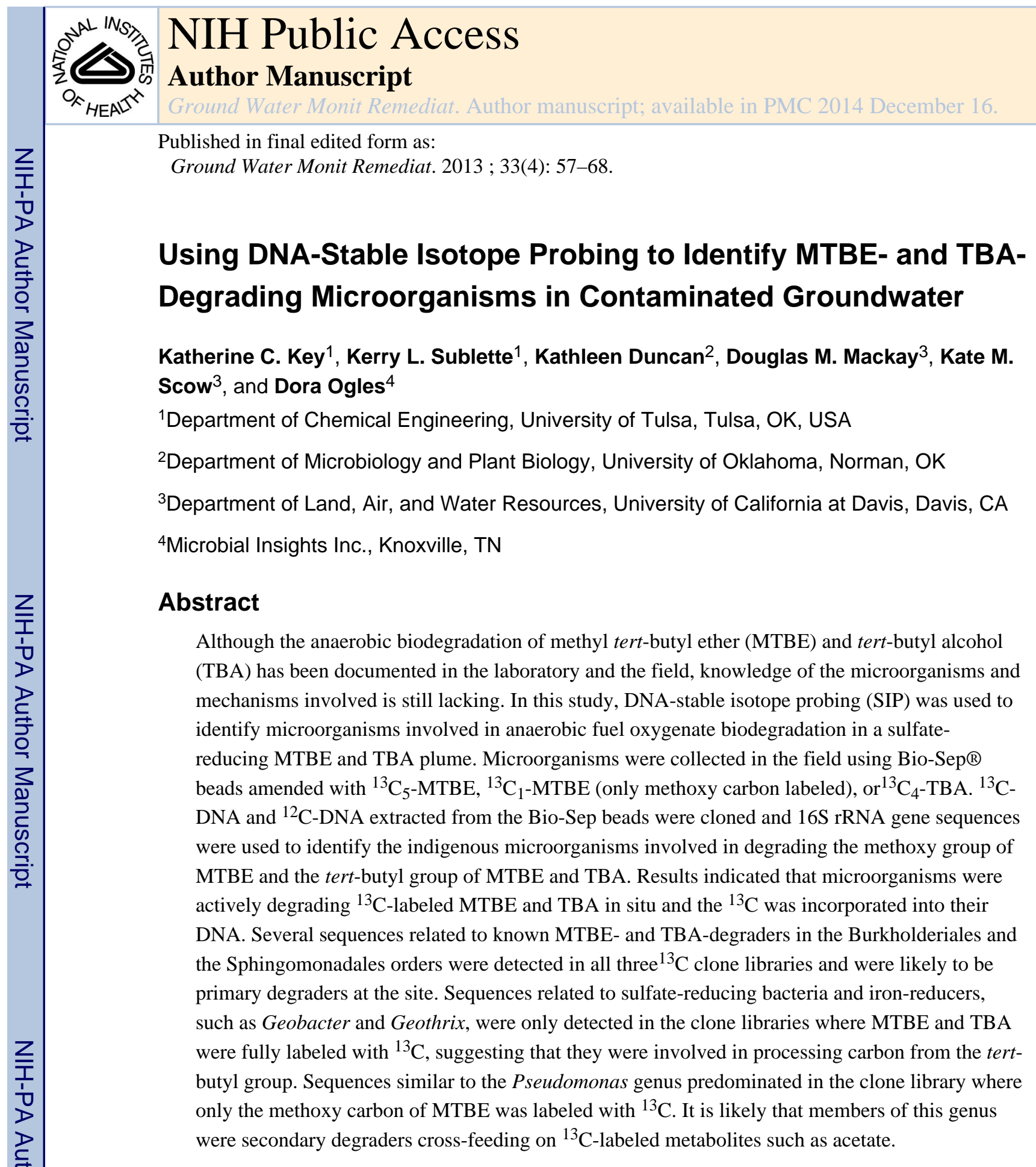

\title{
INTRODUCTION
}

Methyl tert-butyl ether (MTBE) has been widely used as a fuel oxygenate. It was first added to gasoline in the late 1970s as tetra-ethyl lead was phased out. To reduce air emissions and comply with the Clean Air Act Amendments passed in 1990, MTBE use as a fuel additive increased with concentrations in gasoline ranging between $11 \%$ and $15 \%$ by volume (Fiorenza and Rifai 2003). While the addition of MTBE did result in cleaner-burning fuel, it

Send page proofs to: Kerry L. Sublette, Dept. of Chemical Engineering, University of Tulsa, 800 South Tucker Drive, Tulsa, OK 74104, kerry-sublette@utulsa.edu. 
proved to be a significant contributor to groundwater pollution at sites where gasoline had been leaked or spilled. Due to these environmental issues, MTBE is now banned in several states, and it has largely been replaced with ethanol. MTBE is 20 times more water soluble $(50 \mu \mathrm{g} / \mathrm{L}$ at room temperature) and less volatile than benzene, toluene, ethylbenzene, and xylene (BTEX), so it rapidly migrates in groundwater and creates larger contaminant plumes than BTEX (Davis and Erickson 2004). Since MTBE also has a low adsorption onto organic matter, adsorption to the sediments does not significantly retard the contaminant's migration. tert-Butyl alcohol (TBA) is frequently found as a co-contaminant with MTBE. TBA may be present as an added component or an impurity in gasoline, and it is also a key intermediate in MTBE biodegradation.

MTBE and TBA are capable of being degraded through aerobic respiration (Salanitro et al. 1994; Hanson et al. 1999; Deeb et al. 2001; Wilson et al. 2001; Bradley et al. 2002), denitrification (Bradley et al. 2001, 2002), iron (III) reduction (Landmeyer et al. 1998; Bradley et al.2001; Finneran and Lovley 2001), and sulfate reduction (Bradley et al. 2001, 2002; Somsamak et al. 2001, 2006). The biodegradation of MTBE by methanogenesis has been documented, but TBA appears to be recalcitrant under methanogenic conditions (Mormile et al. 1994; Wilson et al. 2000; Bradley et al. 2001, 2002; Somsamak et al. 2006). The persistence of these compounds in several studies suggests that the necessary microorganisms are not ubiquitous in the subsurface (Suflita and Mormile 1993; Kane et al. 2001). The ether bond and the tert-butyl group are difficult for most microorganisms to metabolize, which has contributed to the recalcitrance of MTBE and TBA (Suflita and Mormile 1993; White et al. 1996; Fiorenza and Rifai 2003).

Although anaerobic degradation pathways for MTBE have not been determined in detail, all reports of anaerobic MTBE biodegradation indicate that MTBE is initially O-demethylated to TBA, and TBA has been documented as an intermediate in anaerobic field and laboratory research (Schmidt et al. 2004; Wilson et al. 2005; Youngster et al. 2008). Acetogenic bacteria are known to O-demethylate aryl aromatic ethers, and it is likely that the initial step in MTBE degradation is mediated by acetogens (Kuder et al. 2005; Mackay et al. 2007). Acetogens can further degrade the methyl group through acetogenesis, and the acetate produced can be readily used by a variety of microorganisms in the subsurface community (Weber et al. 1984; Youngster et al. 2010). Youngster et al. (2008) examined the role of acetogens in MTBE degradation and found that MTBE-degrading enrichment cultures could degrade other aromatic ethers and that the addition of aromatic ethers as co-substrates increased MTBE degradation rates. Youngster et al. (2008) also found that MTBE biodegradation was inhibited by propyl iodide. This provided more evidence for an initial Odemethylation mechanism because propyl iodide has been shown to inhibit O-demethylation dependent on a corrinoid-containing protein acting as a methyl acceptor (Choi et al. 1994; Naidu and Ragsdale 2001).

Since oxygen is rapidly depleted in hydrocarbon-impacted groundwater, understanding the microorganisms involved in anaerobic MTBE degradation and the conditions necessary for sufficient biodegradation rates are important areas of research. No anaerobic MTBEdegrading microorganisms have been isolated to date, but the composition of microbial consortia has recently begun to be investigated. In a study characterizing anaerobic MTBE- 
degrading cultures, 16S-rDNA-based amplified ribosomal DNA restriction analysis indicated the presence of novel microorganisms that were not closely related to any known genera or species (Wei and Finneran 2009). Raynal et al. (2010) analyzed 16S rRNA from three microbial consortia utilizing either iron (III), sulfate, or a combination of the two as electron acceptors, and identified microorganisms that were related to known MTBE degraders at the genus or species level, includingAchromobacter, Pseudomonas spp., Rhodococcus, and Sphinogomonas. One of the 16S rRNA gene sequences was 99\% similar toOchrobactrum cytisi, a known MTBE degrader. In another study, anaerobic enrichment cultures established from three sources, each of which had retained the ability to degrade MTBE for over a decade, were characterized using terminal-restriction fragment length (TRFLP) analysis of 16S rRNA genes (Youngster et al. 2010). The community profiles of the three cultures were considerably different, suggesting that multiple species were involved in MTBE biodegradation. Deltaproteobacteria, Firmicutes, and Chloroflexi were the dominant phylotypes indicated by T-RFLP analysis.

DNA-based stable isotope probing (SIP) has also been used to identify MTBE- and TBAdegrading microorganisms. DNA-SIP is a method that traces the fate of a carbon-13 (13C)amended contaminant as it is biodegraded and incorporated into DNA (Radajewski et al. 2000,2003; Dumont and Murrell 2005; Madsen 2006; Neufeld et al. 2007a, 2007b). DNASIP can provide an important link between metabolic activity and phylogeny, which is often lacking in the study of mixed cultures. In a recent DNA-SIP study of MTBE degradation in methanogenic microcosms, bacteria from the Ruminococcaceae family and the Sphingopyxis genus and archaea from theMethanosarcina and Methanocorpusculum genera had 13C-enriched DNA and were identified as the dominant MTBE degraders in a culture from a wastewater treatment plant (Sun et al. 2012). In a study of TBA-degraders cultured from aerobic granulated activated carbon bioreactors, all microorganisms detected using DNA-SIP belonged to the Burkholderiales order of the Betaproteobacteria. Four functional genes that have been associated with TBA oxidation in pure cultures were also detected in the 13C-metagenomic DNA (Aslett et al. 2011).

Most SIP studies have been performed on enrichment cultures in microcosms where variables such as carbon sources and electron acceptor availability can be controlled. However, microcosms can never completely replicate in situ conditions, and it is estimated that only a fraction of the microorganisms in the environment are currently capable of being cultured (Amann et al. 1995; Hugenholtz et al. 1998). While SIP field studies are inherently less controlled than laboratory studies, they can be used to document biodegradation by indigenous microorganisms under actual aquifer conditions. Numerous field studies have been conducted using bio-traps containing Bio-Sep® beads (University of Tulsa, Tulsa, OK, USA) amended with a 13C-labeled compound deployed in monitoring wells (Geyer et al. 2005; Busch-Harris et al. 2006, 2008a; Fiorenza et al. 2009; Chiang et al. 2012). After an incubation period, the bio-traps are retrieved and PLFA, dissolved inorganic carbon, and/or methane are extracted for stable isotope analysis. MTBE and TBA biodegradation has been documented in anaerobic aquifers using this method (Busch-Harris et al. 2008a). However, PLFA cannot provide the taxonomic information that DNA can. 
The objective of this study was to identify indigenous microorganisms involved in degrading the methoxy group and the tert-butyl group of MTBE and TBA in the first DNASIP field study to use bio-traps for these chemicals. Bio-Sep beads amended with 13C5MTBE, 13C1-MTBE (methoxy carbon labeled), or 13C4-TBA were incubated in a sulfatereducing MTBE and TBA plume at Vandenberg Air Force Base in Lompoc, CA. 13C-DNA and 12C-DNA extracted from the Bio-Sep beads were cloned and sequenced to identify the microorganisms involved in MTBE and TBA biodegradation.

\section{SITE DESCRIPTION}

Site 60 at Vandenberg Air Force Base (VAFB) in Lompoc, California, is the location of a former gas station, and has been described previously (Mackay et al. 2006, 2007; North et al. 2012). In 1994, a leak was responsible for the release of an estimated 572 gallons (2165 L) of gasoline. Underground storage tanks and piping were excavated in 1995, and the area was backfilled with gravel, sand, and site sediment. A site map including the excavated area and the monitoring wells used in this study is shown in Figure 1. Downgradient from the backfill, the subsurface is composed of layers of silt and clayey silt interspersed with several thin, horizontal layers of sand. Site groundwater in the $\mathrm{S} 3$ aquifer occurs between approximately 2.5 and $3.5 \mathrm{~m}$ below-ground surface (bgs) and was estimated to flow to the northeast during the study period. Sulfate was the primary electron acceptor in site groundwater, and no dissolved oxygen was detectable in the plume.

The predominant contaminant along the centerline of the plume emanating from the former source area from 1995 through 2004 was MTBE (Mackay et al. 2006). During that time, the MTBE plume extended at least $520 \mathrm{~m}$ whereas the BTEX extended no further than $25 \mathrm{~m}$ from the source. By 2004, BTEX were at very low concentrations; for example TPHg was less than $0.04 \mathrm{mg} / \mathrm{L}$. After 2004, the predominant contaminant within the aquifer at and downgradient of B1 (Figure 1) was TBA. The most likely cause of the shift in plume composition was in situ transformation of MTBE to TBA stimulated by experimental injection of ethanol into the aquifer starting in 2004 (Mackay et al. 2007; Rasa et al. 2011). Even after cessation of ethanol addition in 2005, TBA continued to be the dominant volatile organic carbon (VOC) in the plume, suggesting the transformation of MTBE to TBA was initiated somehow by ethanol addition but persisted even after ethanol addition ceased (Rasa et al. 2011). A subsequent injection experiment in 2005 to 2006 included injection of MTBE- and ethanol-spiked groundwater in one lane and TBA spiked groundwater into wells upgradient of B1 at an average concentration of $2.8 \mathrm{mg} / \mathrm{L}$ (unpublished results). BTEX concentrations decreased below detectable levels, but MTBE and TBA continued to emanate from the source area, with concentrations decreasing slowly (Rasa et al. 2011). These observations suggested that BTEX biodegradation processes have been more ubiquitous and effective than the processes responsible for the biodegradation of MTBE and TBA.

In 2008, bio-traps were deployed in the following 2-in (5.1-cm) monitoring wells: B2, B5-1, B5-2, and B5-3. In early July 2008, groundwater sampling of wells B1-1, B1-2, and B1-3 the three wells immediately upgradient from B2, indicated that TBA concentrations in these wells were $32 \mu \mathrm{g} / \mathrm{L}, 138 \mu \mathrm{g} / \mathrm{L}$, and $5 \mu \mathrm{g} / \mathrm{L}$, respectively, and MTBE concentrations were 12 $\mu \mathrm{g} / \mathrm{L}, 46 \mu \mathrm{g} / \mathrm{L}$, and $4 \mu \mathrm{g} / \mathrm{L}$, respectively. In August 2008 no MTBE was detected in the three 
wells in transect EJ (Figure 1) that were approximately $7.6 \mathrm{~m}$ immediately downgradient of the B5 wells, but TBA concentrations in these wells ranged between $117 \mu \mathrm{g} / \mathrm{L}$ and $192 \mu \mathrm{g} / \mathrm{L}$. Contaminant concentrations in the B5 wells were not monitored before or during the study, but they are near the plume centerline and thus likely to have had very similar concentrations as observed in transects downgradient, as was the case for other monitoring events for months before and after this study.

\section{MATERIALS AND METHODS}

\section{Bio-Sep Bio-Traps}

All bio-traps consisted of a 15.24-cm long, 2.54-cm diameter Schedule 40 PVC tubes with two rows of 1.6-mmslots $3 \mathrm{~mm}$ apart along the entire tube length to allow groundwater contact with the Bio-Sep beads. The tubes were sealed at both ends with PVC end caps that were held in place with stainless steel set screws. All PVC parts were washed with methanol prior to use. The bio-traps were filled with approximately 450 Bio-Sep beads either amended with 13C5-MTBE (fully labeled with 13C), 13C1-MTBE (methoxy carbon labeled only), or13C4-TBA (fully labeled with 13C) (99 + \%; Sigma Aldrich, Miamisburg, Ohio). Bio-Sep beads were amended with MTBE or TBA by vapor-phase adsorption under reduced pressure as described previously (Geyer et al. 2005). The fully labeled MTBE amendment was 100\%13C5-amended MTBE, and the total MTBE concentration on the beads was 0.46 $\pm 0.025 \mathrm{mg} /$ bead (mean \pm standard deviation, $\mathrm{n}=3$ ). The MTBE amendment with only the methoxy carbon labeled was $100 \%$ 13C1-amended MTBE, and the total MTBE concentration on the beads was $0.59 \pm 0.026 \mathrm{mg} / \mathrm{bead}$. The fully labeled TBA amendment was $100 \%$ 13C4-amended TBA, and the total TBA concentration on the beads was $1.03 \pm$ $0.06 \mathrm{mg} / \mathrm{bead}$. The bio-traps were assembled under sterile conditions and stored in sterile Whirl-pak® bags (Nasco, Fort Alkinson, Wisconsin) at $4{ }^{\circ} \mathrm{C}$ until deployed.

\section{Bio-Trap Deployment}

In July 2008, two 13C1-MTBE-amended bio-traps were deployed in well B2. The top trap was installed $30.5 \mathrm{~cm}$ below the water table, and the second trap hung $30.5 \mathrm{~cm}$ below the first. At the same time, wells B5-1 and B5-3 received one 13C4-TBA-amended bio-trap each, both suspended $30.5 \mathrm{~cm}$ below the water table. Two 13C4-TBA-amended bio-traps were installed in well B5-2. The two bio-traps in well B5-2 were separated by $30.5 \mathrm{~cm}$, and the top of the first bio-trap was $30.5 \mathrm{~cm}$ below the water table. After a 41-d incubation period, all bio-traps were retrieved and shipped overnight, on ice to Microbial Insights Inc. (Knoxville, Tennessee) for DNA extraction and separation into 12C- and 13C-DNA fractions. On the same day, two 13C5-MTBE-amended bio-traps were deployed in well B2. The two bio-traps were separated by $30.5 \mathrm{~cm}$, and the top of the first bio-trap was installed $30.5 \mathrm{~cm}$ below the water table. After a 49-d incubation period, the bio-traps were retrieved and shipped overnight, on ice to Microbial Insights for DNA extraction and separation into 12C- and 13C-DNA fractions.

\section{Bio-Sep Bead Analysis}

Bio-Sep Bead MTBE and TBA Analysis-Bio-Sep beads were shipped from Microbial Insights to the University of Tulsa (Tulsa, Oklahoma) for gas chromatography-mass 
spectrometry (GC-MS) analysis of MTBE and TBA concentrations. The MTBE and TBA concentrations in Bio-Sep beads were determined by extraction with methylene chloride (1 $\mathrm{mL} /$ bead), followed by GC-MS analysis. Analysis was performed on a GC-MS QP5000 (Shimadzu Scientific Instruments Inc., Columbia, MD, USA) using a 5-point calibration curve. 13C5-MTBE, 13C1-MTBE, and 13C4-TBA concentrations in extracts were determined by selected ion monitoring using ions $(\mathrm{m} / \mathrm{z})$ of 77,74 , and 63 , respectively (Busch-Harris et al. 2008a). Contaminant concentration in Bio-Sep beads are reported here as the mean \pm standard deviation $(\mathrm{n}=3)$.

Separation of 13C-DNA and 12C-DNA: DNA was extracted from the Bio-Sep beads using a MO BIO Power Soil DNA kit (MO BIO Laboratories Inc., Carlsbad, California). 13CDNA was isolated from $12 \mathrm{C}$-DNA using cesium chloride $(\mathrm{CsCl})$ density gradient centrifugation (Radajewski et al. 2000; Gallagher et al. 2005). Ultracentrifuge tubes were filled with $1.0 \mathrm{~g}$ of $\mathrm{CsCl}$ dissolved in $1000 \mu \mathrm{L}$ of TE buffer (10 mM TRIS, $1 \mathrm{mM}$ EDTA, pH 7.5), $20 \mu \mathrm{L}$ of ethidium bromide $(10 \mathrm{mg} / \mathrm{mL})$, and $600 \mathrm{ng}$ of DNA. The tubes were sealed and centrifuged at $75,000 \mathrm{rpm}$ for $48 \mathrm{~h}$ at $20^{\circ} \mathrm{C}$. Two bands spaced about 9 to $12 \mathrm{~mm}$ apart were visible in the tubes after centrifugation, and the bands were withdrawn separately using sterile 18 gauge needles. To remove the ethidium bromide, 10 to 20 volumes of 1-butanol were mixed with each band, and the organic layer was discarded. This process was repeated 4 to 5 times until all ethidium bromide was removed. One-tenth TE buffer was added to bring the volume of the extracted DNA up to $500 \mu \mathrm{L}$, and $50 \mu \mathrm{L}$ of $3 \mathrm{M}$ sodium acetate (pH 5.2), $1 \mu \mathrm{L}$ of glycogen, and $1000 \mu \mathrm{L}$ of cold $100 \%$ isopropanol were added. The DNA fractions were stored at $-20{ }^{\circ} \mathrm{C}$ for at least an hour and then centrifuged at $13,000 \mathrm{rpm}$ for $30 \mathrm{~min}$. The supernatant was poured off, and $500 \mu \mathrm{L}$ of cold $70 \%$ ethanol was added. The DNA fractions were centrifuged at 13,000 rpm for 5 min two times, with the supernatant discarded after each time. After the pellets of DNA were dry, the isolated DNA fractions were resuspended in $50 \mu \mathrm{L}$ of 1/10 TE buffer. The DNA fractions were sent to the University of Oklahoma (Norman, Oklahoma) for polymerase chain reaction (PCR) amplification and cloning.

\section{DNA Cloning and Sequencing}

DNA cloning was performed by Dr. Kathleen Duncan at the University of Oklahoma (Norman, Oklahoma). Six clone libraries were created, a 13C-DNA and a 12C-DNA library from each of the three types of bio-traps: 13C5-MTBE, 13C1-MTBE, and 13C4-TBA. Primers (e.g., $27 \mathrm{~F}$ and 1391R) and PCR reaction conditions as recommended by the DOE Joint Genome Institute (http://my.jgi.doe.gov/general/protocols/ SOP_16S18S_rRNA_PCR_Library_Creation.pdf) were used to amplify approximately 1350 to 1400 base pairs (bp) of the eubacterial $16 \mathrm{~S}$ rRNA gene sequence. The PCR products were cloned into the TOPO-TA vector (Invitrogen, Carlsbad, California), and the manufacturer's instructions were followed to maximize the diversity of sequences cloned. Transformed colonies were inoculated into a 96-well plate containing tryptone-yeast extract glycerol broth with ampicillin (Elshahed et al. 2003). The colonies were grown overnight at $37^{\circ} \mathrm{C}$ and stored at $-80^{\circ} \mathrm{C}$ until sequencing. DNA sequencing was performed by Microgen (Oklahoma City, Oklahoma) using an ABI 3730 Capillary Sequencer and M13F and M13R primers. 


\section{Sequence Analysis}

The SEQUENCHER program (Gene Codes Corp., Ann Arbor, Michigan) was used to view the chromatograms and assemble consensus sequences from the contigs. The greengenes NAST-aligner was used to align the sequences, and Bellerophon (Version 3,http:// greengenes.lbl.gov/cgi-bin/nph-bel3_interface.cgi) was used to detect and remove chimeras. The DOTUR program (Schloss and Handelsman 2005) used distance matrices (DeSantis et al. 2006) created from the $16 \mathrm{~S}$ rRNA gene sequence libraries to group sequences sharing 97\% similarity into operational taxonomic units. One representative sequence was selected from each operational taxonomic unit, and taxonomic affiliations were determined by the Ribosomal Database Project Classifier (Wang et al. 2007). BLASTN (Altschul et al. 1997) was used to identify the closest match to representative sequences in the GenBank database. Good's method (1953) was used to estimate the percentage library coverage at the $97 \%$ level of similarity. The representative sequences determined in this study have been submitted to the GenBank database and assigned nucleotide sequence accession numbers KC758898 to KC758957. Sequences of type strains, obtained from the SEQMATCH program (Cole et al., 2008) that most closely matched representative sequences and outgroup sequences were aligned using ClustalX (Version 1.81) (Thompson et al. 1997). The neighbor-joining method of Saitou and Nei (1987) was used to demonstrate the phylogenetic relationships among selected sequences, as implemented in ClustalX (Thompson et al. 1997). The support for the tree branches was estimated from 1000 bootstrap replicates (Felsenstein 1985). Only representative sequences for two or more sequences were used for construction of the phylogenetic trees.

\section{RESULTS AND DISCUSSION}

Prior to deployment, the Bio-Sep beads were amended with 13C5-MTBE, 13C1-MTBE, or 13C4-TBA. A comparison of the initial and post-incubation MTBE and TBA concentrations is shown in Table 1. In each case, 13C-labeled oxygenate was lost from all bio-traps during the incubation period, possibly in part due to leaching, but isotopic analysis of DNA provided evidence that some loss was due to biodegradation. Although contaminant concentrations were not measured after the first deployment of bio-traps, groundwater samples collected from well B2 $1 \mathrm{~d}$ after the 13C5-MTBE bio-traps were removed showed significant MTBE and TBA concentrations $(23.6 \mathrm{mg} / \mathrm{L}$ and $9.6 \mathrm{mg} / \mathrm{L}$, respectively). Most of the MTBE was presumably from the MTBE-amended bio-traps from the first and second deployments, and the TBA was likely a biotransformation product of the MTBE. In an ex situ study of 13C5-MTBE and 13C4-TBA bio-traps at the VAFB Site 60, researchers found that approximately $90 \%$ of the TBA and $45 \%$ of the MTBE desorbed from the Bio-Sep beads during a 6-week time period, with the majority of the mass lost during the first few days of the study (North et al. 2012).

Evidence of 13C incorporation into microbial DNA was found in all three types of bio-traps, indicating that microorganisms present at the site were capable of degrading MTBE and TBA. Six clone libraries were developed from the 13C- and 12C-DNA extracted from the 13C5-MTBE, 13C1-MTBE, and 13C4-TBA bio-traps. A total of 205 sequences from the 6 clone libraries were analyzed and grouped into 60 operational taxonomic units based on 
$97 \%$ sequence similarity. Libraries ranged from 26 to 41 sequences. Library coverage was estimated by Good's method (Good 1953). The 13C1-MTBE clone library had the highest percent coverage (93\%), suggesting that the majority of the microorganisms in this sample were represented in the clone library. The 12C clone library from the 13C5-MTBE bio-trap had the lowest percent coverage (58\%), indicating that additional sequencing of clones from this sample would be expected to yield additional phylotypes. The number of sequences and operational taxonomic units found in each clone library and library coverage are shown in Table 2.

A variety of microorganisms had incorporated $13 \mathrm{C}$ from the labeled MTBE or TBA into their DNA. Thirty-nine operational taxonomic units were identified in the 13C-DNA clone libraries, 19 of which were unique to the 13C-DNA and not detected in any of the 12C-DNA libraries. The number of operational taxonomic units shared by any two samples is summarized in Table 3 . The dissimilarity between the 12C-and13C-clone libraries suggested that the 13C-DNA sequences represented a sub-sample from the total microbial population of microorganisms involved in MTBE and TBA biodegradation. The three 13Cclone libraries were also dissimilar from each other, suggesting that different microorganisms were involved in processing the methoxy carbon and the tert-butyl group of MTBE and TBA.

A summary of the most abundant class, order, and genus for each of the clone libraries based on Ribosomal Database Project Classifier results is shown in Table 4, and graphs of affiliations for the 13C- and 12C-DNA clone libraries are shown in Figures 2 through 5. Complete Ribosomal Database Project Classifier and BLASTN results for each operational taxonomic unit are included in Table S1(Supporting Information) and the phylogenetic affiliation of the operational taxonomic units to those of bacterial type strains are shown in Figure 6A and 6B. Three relevant features of this dataset emerge when comparing clone libraries: (1) Gammaproteobacteria, specifically the genus Pseudomonas, predominated in the 13C1-MTBE clone library; (2) Deltaproteobacteria were detected in the 13C5-MTBE and13C4-TBA clone libraries but were absent from the 13C1-MTBE clone library, and (3) multiple operational taxonomic units related to known MTBE- and TBA-degraders were identified in all three $13 \mathrm{C}$ clone libraries.

As shown in Table 4, the 13C1-MTBE clone library was primarily composed of Gammaproteobacteria (78\%), and 19 of these sequences were most similar (99\% over 1396 nucleotides) to Pseudomonas fluorescens (CP003041.1) (Loper et al. 2012). This suggested that this operational taxonomic unit (KC758942) was involved in processing the 13Clabeled methoxy carbon. This operational taxonomic unit was also detected in the 13C4TBA library (4 sequences), the 12C library from the 13C1-MTBE bio-trap (7 sequences), and the 12C clone library from the 13C4-TBA bio-trap (2 sequences) (Figures 4 and 5). Pseudomonas is a large genus known for its ubiquity in the environment and ability to metabolize a variety of organic compounds (Lessie and Phibbs 1984; Kukor and Olsen 1990; Ahn et al. 1998; Abuhamed et al.2004; Wu et al. 2011). It is unclear whether this Pseudomonas operational taxonomic unit was a primary degrader of MTBE or if it was feeding on the resulting metabolites since cross-feeding of isotopically labeled metabolites can occur during DNA-SIP experiments (Radajewski et al. 2003). 
P. fluorescens has been observed to grow on acetate (Kornberg 1958), so this operational taxonomic unit may be outcompeting other microorganisms for the acetate intermediate of MTBE degradation. Research has shown that acetogenic microorganisms are likely involved in the initial O-demethylation of MTBE, and a variety of microorganisms are capable of assimilating the resulting acetate (Kuder et al. 2005; Mackay et al. 2007; Youngster et al. 2010). Pseudomonas species that have been directly linked to MTBE degradation have been most frequently reported degrading MTBE co-metabolically with hydrocarbons, which would not result in 13C being directly incorporated into the microorganism's DNA (Garnier et al. 1999; Smith and Hyman 2004; Schmidt et al. 2004).

In future studies, retrieving bio-traps at different time periods may provide a better picture of the sequence of carbon flow through the microbial population. In a DNA-SIP microcosm study of MTBE-degrading enrichment cultures conducted by Youngster (2009), T-RFLP profiles of samples collected from six cultures at six time-points indicated that some microorganisms incorporated $13 \mathrm{C}$ earlier than others, presumably the microorganisms directly involved in MTBE biodegradation. After $35 \mathrm{~d}$, T-RFLP profiles from 12C-and 13C-DNA were highly similar, which suggested that the $13 \mathrm{C}$ was spreading through the community through cross-feeding.

Deltaproteobacteria were detected in the 13C5-MTBE and 13C4-TBA clone libraries but were absent from the 13C1-MTBE clone library (Figure 2). This class includes several ironreducers and sulfate-reducing bacteria (SRB). Sequences with 100\% similarity over 1413 nucleotides to the iron-reducing genus Geobacter (KC758938, KC758939) were detected in both the 13C4-TBA (4 sequences) and 13C5-MTBE (8 sequences) clone libraries. Clones related to Geobacter have been identified in previously characterized MTBE-degrading enrichment cultures (Raynal et al. 2010; Youngster et al. 2010). The 13C4-TBA clone library also contained a sequence similar (100\% over 1397 nucleotides, KC758898) to Geothrix, an iron-reducing microorganism in the Acidobacteria class (Nevin and Lovley 2002). The 13C4-TBA clone library included sequences with $100 \%$ similarity to the following SRB: Desulfobulbus (2 sequences, KC758932, 1418 nucleotides), Desulfovibrio (4 sequences, KC758934, 1409 nucleotides), Desulfuromonas (3 sequences, KC758936, 1416 nucleotides), and an unclassified bacterium from the Desulfobulbaceae family (1 sequence, $\mathrm{KC} 758933,1403$ nucleotides). The 13C5-MTBE clone library also contained one sequence (KC758936) similar (100\% over 1416 nucleotides) to Desulfuromonas. These results suggested that iron reducers and SRB were involved in processing the carbon from the degradation of TBA or the tert-butyl group of MTBE since they were not detected in the 13C1-MTBE clone library where only the methoxy carbon was labeled.

The opposite trend was observed in a previous SIP study where SRB appeared to be more involved in processing the methoxy carbon of MTBE than the tert-butyl group (BuschHarris et al. 2008b). In the study, anaerobic sediments from MTBE-contaminated aquifers were added to sulfate-amended microcosms containing Bio-Sep beads amended with either 13C5-MTBE, 13C1-MTBE (methoxy carbon labeled), 13C3-MTBE (tert-butyl group labeled), or 13C4-TBA. After 4 months, PLFA was extracted from the Bio-Sep beads and analyzed for 13C enrichment. 13C-labelling was evident in PLFA from the 13C5-MTBE and 13C1-MTBE microcosms, and 10me16:0, a biomarker associated with the sulfate-reducer 
Desulfobacter (Dowling et al. 1986; Kohring et al. 1994), was highly enriched with 13C. However, theDesulfobacter biomarker from the 13C4-TBA microcosm was less 13Cenriched, and no 13C-labeling was detected in PLFA from the13C3-MTBE microcosm. One possible explanation the differences in metabolic activity exhibited by SRB in the PLFA-SIP study and this study is that some SRB involved in biodegradation may not have been identified by PLFA-SIP, since PLFA analysis cannot identify taxonomy with the precision of DNA sequencing. Also, Desulfobacter was the microorganism associated with the degradation of the methoxy group in the PLFA-SIP study, but it was not among the SRB genera detected in this study.

13C-DNA from the 13C5-MTBE or 13C4-TBA clone libraries was more likely to represent primary degraders than 13C-DNA from the 13C1-MTBE clone library since TBA is more persistent in the environment than metabolites from the methoxy group, such as acetate, and TBA accumulation has been previously documented at VAFB Site 60 (Mackay et al. 2007). Several sequences from the 13C5-MTBE or 13C4-TBA clone libraries were related to known aerobic MTBE and TBA degraders or microorganisms that had been previously identified in MTBE-degrading enrichment cultures. Since wells were sealed at the surface and the aquifer was relatively shallow, aerobic microorganisms may have been supported by oxygen diffusing from the surface or from unimpacted groundwater outside of the plume.

Burkholderiales was the most abundant order (24\%) in the 13C5-MTBE library (Table 4), and four sequences in the 13C4-TBA clone library and five sequences in the 13C1-MTBE clone library also belonged to this order (Figure 4). Genera identified as members of order Burkholderiales included Hydrogenophaga, Rhodoferax, Aquabacterium, and Achromobacter. Three sequences from the 13C4-TBA library and three sequences from the 13C5-MTBE library (KC758925) had 100\% similarity to Hydrogenophaga over 1388 nucleotides, and six sequences from the 13C5-MTBE library (KC758926) were 95\% similar to Rhodoferax over 1392 nucleotides. An operational taxonomic unit with $99 \%$ similarity over 1390 nucleotides to Aquabacterium was detected in the 13C1-MTBE and 13C5-MTBE libraries (KC758924). Four sequences from the 13C1-MTBE clone library (KC758923) were $100 \%$ similar to Achromobacter over 1390 nucleotides. The 13C4-TBA clone library contained an operational taxonomic unit of unclassified genus (KC758927) with 99\% similarity over 1393 nucleotides to the Oxalobacteraceae family in the Burkholderiales order.

Many known aerobic MTBE and TBA degraders belong to Burkholderiales, including Methylibium petroleiphilum PM1 (Hanson et al. 1999),Aquincola tertiaricarbonis L108 (Müller et al. 2008), and Hydrogenophaga flava ENV735 (Steffan et al. 1997; Hatzinger et al. 2001). In a DNA-SIP study conducted on TBA-utilizing microorganisms from oxygenated granulated activated carbon reactors, all 13C-DNA clones belonged to Burkholderiales, including a sequence similar to Hydrogenophaga taeniospiralis (98.5\%) and one similar to Rhodoferax ferrireducens (99.1\%) (Aslett et al. 2011). These two genera belong to Comamonadaceae, which also contains M. petroleiphilum PM1.Aquabacterium has also been reported as a close relative of M. petroleiphilum PM1 (Bruns et al. 2001). An Achromobacter clone was detected in MTBE-degrading cultures under both sulfate- and 
iron-reducing conditions (Raynal et al. 2010), and Achromobacter xylosoxidans MCM1/1 is reported to be capable of MTBE degradation (Eixarch and Constantí 2010).

Sequences with $100 \%$ similarity to Sphingobium (class Alphaproteobacteria, family Sphingomonadaceae) were detected in the 13C4-TBA (1 sequence) and 13C1-MTBE libraries (2 sequences, KC758922, 1347 nucleotides). In a DNA-SIP study of MTBE degradation in methanogenic microcosms, 18 clones enriched with $13 \mathrm{C}$ were related to Sphingopyxis of the Sphingomonadaceae family (Sun et al. 2012). The Sphingomonas genus in this family has also been associated with MTBE degradation. A Sphingomonas strain able to grow aerobically with only MTBE as a carbon source has been isolated (Okeke and Frankenberger 2003), and Sphingomonas has been identified in MTBE-degrading consortia in bioreactors (Pruden et al. 2001; Zein et al. 2004). Additionally, a clone 98\% similar toSphingomonas was detected in an iron-reducing microcosm of an MTBE-degrading enrichment culture (Raynal et al. 2010).

In contrast to the operational taxonomic units classified as Proteobacteria, the sequences affiliated with Spirochaetes, Bacteroidetes, Firmicutes, and other groups often were only distantly related to described strains of bacteria (Figure 6B). Hence, although such sequences were relatively abundant in our samples and in other subsurface bioremediation sites (see Supporting Information), their role, if any, in MTBE degradation remains unknown.

\section{CONCLUSIONS}

Results from this study demonstrated that microorganisms were actively degrading 13Clabeled MTBE and TBA in bio-traps in situ and the $13 \mathrm{C}$ was incorporated into their DNA. The most frequently detected operational taxonomic unit in the 13C1-MTBE clone library was 99\% similar to P. fluorescens. Although some Pseudomonas species have been reported to co-metabolically degrade MTBE with hydrocarbons (Garnier et al. 1999; Smith and Hyman 2004; Schmidt et al. 2004), it is likely that this species was cross-feeding on 13Clabeled metabolites and was a secondary degrader. P. fluorescens has been reported to grow on acetate (Kornberg 1958), a product associated with the O-demethylation and subsequent acetogenesis of MTBE. The operational taxonomic units in the 13C1-MTBE clone library related to Aquabacterium, Achromobacter, and Sphingobium are more likely to be involved in the initial step of MTBE degradation since these genera are related to previously documented MTBE degraders.

Operational taxonomic units from the 13C5-MTBE and 13C4-TBA libraries were likely to represent primary degraders since TBA is much more persistent in the environment than the intermediates resulting from the O-demethylation of MTBE. Several operational taxonomic units from these clone libraries were related to known MTBE and TBA degraders or microorganisms identified in MTBE-degrading enrichment cultures, especially the four operational taxonomic units related to the Burkholderiales order. Many operational taxonomic units related to SRB and iron-reducing genera were also detected in the 13C5MTBE and 13C4-TBA libraries, suggesting that they were involved in processing carbon from the tert-butyl group. 
Additional microorganisms involved in the carbon flow from MTBE and TBA degradation may not have been identified by DNA-SIP due to its low sensitivity. Slow growth and degradation rates have been reported for many MTBE-degrading isolates (Hanson et al. 1999; Deeb et al. 2001; François et al. 2002). MTBE degraders also grow more slowly on 13C-MTBE than 12C-MTBE. For example, an MTBE-degrading enrichment culture degraded $300 \mu \mathrm{M}$ 12C-MTBE in approximately $50 \mathrm{~d}$, while only about $150 \mu \mathrm{M} 13 \mathrm{C}-\mathrm{MTBE}$ had been degraded after $60 \mathrm{~d}$ (Youngster 2009). It is possible that slow-growing MTBE- and TBA-degraders had not incorporated enough 13C-DNA or were not present in high enough concentrations to be detected or to dominate the sequences analyzed in this study. In the future, longer bio-trap incubation times may lead to increased detection of any slow-growing organisms.

While microorganisms capable of degrading MTBE and TBA were detected through DNASIP, these contaminants have persisted at VAFB Site 60 for over a decade. The low concentrations (4 to $46 \mu \mathrm{g} / \mathrm{L} \mathrm{MTBE}$ and 5 to $138 \mu \mathrm{g} / \mathrm{L}$ TBA) present in groundwater prior to this study may not have been high enough to induce MTBE and TBE biodegradation. Predeployment concentrations in the Bio-Sep beads (460 $\mu \mathrm{g} / \mathrm{bead} 13 \mathrm{C} 5-\mathrm{MTBE}, 590 \mu \mathrm{g} / \mathrm{bead}$ 13C1-MTBE, and $1000 \mu \mathrm{g} /$ bead 13C4-TBA) were higher than aquifer concentrations, and leaching from the beads significantly increased contaminant concentrations in the monitoring well. These higher concentrations may have stimulated members of the microbial community that were previously dormant (Hyman 2012). Most DNA-SIP studies use concentrations of 13C-labeled materials that are higher than environmentally relevant because DNA is the least sensitive biomarker used in SIP studies. Cell division is required for $13 \mathrm{C}$ to be incorporated into DNA, and DNA must contain a minimum of 15 to $20 \% 13 \mathrm{C}$ to be separated from 12C-DNA (Radajewski et al.2003). In future studies, Bio-Sep beads could be amended with MTBE and TBA in concentrations that are more representative of concentrations at the site. Bio-Sep beads could also be pre-leached in sterile water prior to deployment to remove the most labile fraction of MTBE or TBA and avoid any regulatory issues associated with contaminant releases.

\section{Supplementary Material}

Refer to Web version on PubMed Central for supplementary material.

\section{ACKNOWLEDGEMENT}

This work was funded in part by the American Petroleum Institute.

\section{References}

Abuhamed T, Bayraktar E, Mehmetoğlu T, Mehmetoğlu Ü. Kinetics model for growth of Pseudomonas putida F1 during benzene, toluene and phenol biodegradation. Process Biochemistry. 2004; 39(8):983-988.

Ahn I-S, Ghiorse WC, Lion LW, Shuler ML. Growth kinetics of Pseudomonas putida G7 on naphthalene and occurrence of naphthalene toxicity during nutrient deprivation. Biotechnology and Bioengineering. 1998; 59(5):587-594. [PubMed: 10099376] 
Altschul SF, Madden TL, Schäffer AA, Zhang J, Zhang Z, Miller W, Lipman DJ. Gapped BLAST and PSI-BLAST a new generation of protein database search programs. Nucleic Acids Research. 1997; 25(17):3389-3402. [PubMed: 9254694]

Amann RI, Ludwig W, Schleifer KH. Phylogenetic identification and in situ detection of individual microbial cells without cultivation. Microbiological Reviews. 1995; 59(1):143-169. [PubMed: 7535888]

Aslett D, Haas J, Hyman M. Identification of tertiary butyl alcohol (TBA)-utilizing organisms in BioGAC reactors using 13C-DNA stable isotope probing. Biodegradation. 2011; 22(5):961-972. [PubMed: 21286787]

Bradley PM, Landmeyer JE, Chapelle FH. TBA biodegradation in surface-water sediments under aerobic and anaerobic conditions. Environmental Science and Technology. 2002; 36(19):40874090. [PubMed: 12380079]

Bradley PM, Chapelle FH, Landmeyer JE. Effect of redox conditions on MTBE biodegradation in surface water sediments. Environmental Science and Technology. 2001; 35(23):4643-4647. [PubMed: 11770765]

Bruns MA, Hanson JR, Mefford J, Scow KM. Isolate PM1 populations are dominant and novel methyl tert-butyl ether-degrading bacteria in compost biofilter enrichments. Environmental Microbiology. 2001; 3(3):220-225. [PubMed: 11321538]

Busch-Harris J, Sublette K, Roberts KP, Landrum C, Peacock AD, Davis G, Ogles D, Holmes WE, Harris D, Ota C, Yang X, Kolhatkar A. Bio-traps coupled with molecular biological methods and stable isotope probing demonstrate the in situbiodegradation potential of MTBE and TBA in gasoline-contaminated aquifers. Ground Water Monitoring \& Remediation. 2008a; 28(4):47-62.

Busch-Harris, J.; Sublette, K.; Wilson, JT.; Adair, C.; Yang, X.; Kuder, T.; Philip, P.; Davis, G.; McElroy, D.; Holmes, WE.; Harris, D. International Conference on Remediation of Chlorinated and Recalcitrant Compounds, Abstract K-036. Monterey, California: Battelle Press; 2008b. Stable isotope probing with 13C-MTBE- and 13C-TBA-amended Bio-Sep® beads in sulfate-reducing microcosms.

Busch-Harris J, Jennings EM, Sublette KL, Roberts KP, White DC, Peacock AD, Davis G, Ogles D, Holmes WE, Yang X, Kolhatkar A, Beckmann D, Kolhatkar R. Monitoring subsurface microbial ecology and demonstrating in situbiodegradation potential using Bio-Sep® bio-traps. Ecological Chemistry and Engineering. 2006; 13:349-372.

Chiang S-YD, Mora R, Diguiseppi WH, Davis G, Sublette K, Gedalanga P, Mahendra S. Characterizing the intrinsic bioremediation potential of 1,4-dioxane and trichloroethene using innovative environmental diagnostic tools. Journal of Environmental Monitoring. 2012; 14(9): 2317-2326. [PubMed: 22825917]

Choi S-C, Chase T, Bartha R. Metabolic pathways leading to mercury methylation in Desulfovibrio desulfuricans LS. Applied and Environmental Microbiology. 1994; 60(11):4072-4077. [PubMed: 16349435]

Cole JR, Wang Q, Cardenas E, Fish J, Chai B, Farris RJ, Kulam-Syed-Mohideen AS, McGarrell DM, Marsh T, Garrity GM, Tiedje JM. The Ribosomal Database Project: improved alignments and new tools for rRNA analysis. Nucleic Acids Research. 2008; 37:D141-D145. no. Database issue: [PubMed: 19004872]

Davis LC, Erickson LE. A review of bioremediation and natural attenuation of MTBE. Environmental Progress. 2004; 23(3):243-252.

Deeb RA, Hu H-Y, Hanson JR, Scow KM, Alvarez-Cohen L. Substrate interactions in BTEX and MTBE mixtures by an MTBE-degrading isolate. Environmental Science and Technology. 2001; 35(2):312-317. [PubMed: 11347603]

DeSantis TZ, Hugenholtz P, Keller K, Brodie EL, Larsen N, Piceno YM, Phan R, Andersen GL. NAST: A multiple sequence alignment server for comparative analysis of $16 \mathrm{~S}$ rRNA genes. Nucleic Acids Research. 2006; 34(suppl 2):W394-W399. [PubMed: 16845035]

Dowling NJE, Widdel F, White DC. Phospholipid ester-linked fatty acid biomarkers of acetateoxidizing sulphate-reducers and other sulphide-forming bacteria. Journal of General Microbiology. 1986; 132(7):1815-1825. 
Dumont MG, Murrell JC. Stable isotope probing-Linking microbial identity to function. Nature Reviews Microbiology. 2005; 3(6):499-504.

Eixarch H, Constantí M. Biodegradation of MTBE by Achromobacter xylosoxidans MCM1/1 induces synthesis of proteins that may be related to cell survival. Process Biochemistry. 2010; 45(5):794798.

Elshahed MS, Senko JM, Najar FZ, Kenton SM, Roe BA, Dewers TA, Spear JR, Krumholz LR. Bacterial diversity and sulfur cycling in a mesophilic sulfide-rich spring. Applied and Environmental Microbiology. 2003; 69(9):5609-5621. [PubMed: 12957951]

Felsenstein J. Confidence limits on phylogenies: An approach using the bootstrap. Evolution. 1985; 39:666-670.

Finneran KT, Lovley DR. Anaerobic degradation of methyl tert-butyl ether (MTBE) and tert-butyl alcohol (TBA). Environmental Science and Technology. 2001; 35(9):1785-1790. [PubMed: 11355193]

Fiorenza S, Rifai HS. Review of MTBE biodegradation and bioremediation. Bioremediation Journal. 2003; 7(1):1-35.

Fiorenza S, McClary AC, Lummus S. Use of bio-traps with multiple substrates and electron acceptors to optimize remediation. Remediation Journal. 2009; 20(1):69-85.

François A, Mathis H, Godefroy D, Piveteau P, Fayolle F, Monot F. Biodegradation of methyl tertbutyl ether and other fuel oxygenates by a new strain, Mycobacterium austroafricanum IFP 2012. Applied and Environmental Microbiology. 2002; 68(6):2754-2762. [PubMed: 12039730]

Gallagher E, McGuinness L, Phelps C, Young LY, Kerkhof LJ. 13C-carrier DNA shortens the incubation time needed to detect benzoate-utilizing denitrifying bacteria by stable-isotope probing. Applied and Environmental Microbiology. 2005; 71(9):5192-5196. [PubMed: 16151104]

Garnier PM, Auria R, Augur C, Revah S. Cometabolic biodegradation of methyl t-butyl ether by Pseudomonas aeruginosa grown on pentane. Applied Microbiology and Biotechnology. 1999; 51(4):498-503. [PubMed: 10341433]

Geyer R, Peacock AD, Miltner A, Richnow HH, White DC, Sublette KL, Kastner M. In situ assessment of biodegradation potential using biotraps amended with 13C-labeled benzene or toluene. Environmental Science and Technology. 2005; 39(13):4983-4989. [PubMed: 16053100]

Good IJ. The population frequencies of species and the estimation of population parameters. Biometrika. 1953; 40(3-4):237-264.

Hanson JR, Ackerman CE, Scow KM. Biodegradation of methyl tert-butyl ether by a bacterial pure culture. Applied and Environmental Microbiology. 1999; 65(11):4788-4792. [PubMed: 10543787]

Hatzinger PB, McClay K, Vainberg S, Tugusheva M, Condee CW, Steffan RJ. Biodegradation of methyl tert-butyl ether by a pure bacterial culture. Applied and Environmental Microbiology. 2001; 67(12):5601-5607. [PubMed: 11722912]

Hugenholtz P, Goebel BM, Pace NR. Impact of culture-independent studies on the emerging phylogenetic view of bacterial diversity. Journal of Bacteriology. 1998; 180(18):4765-4774. [PubMed: 9733676]

Hyman M. Biodegradation of gasoline ether oxygenates. Current Opinion in Biotechnology. 2012

Kane SR, Beller HR, Legler TC, Koester CJ, Pinkart HC, Halden RU, Happel AM. Aerobic biodegradation of methyltert-butyl ether by aquifer bacteria from leaking underground storage tank sites. Applied and Environmental Microbiology. 2001; 67(12):5824-5829. [PubMed: 11722940]

Kohring LL, Ringelberg DB, Devereux R, Stahl DA, Mittelman MW, White DC. Comparison of phylogenetic relationships based on phospholipid fatty acid profiles and ribosomal RNA sequence similarities among dissimilatory sulfate-reducing bacteria. FEMS Microbiology Letters. 1994; 119(3):303-308. [PubMed: 7519575]

Kornberg HL. The metabolism of C2 compounds in micro-organisms. I. The incorporation of [2-14C] acetate by Pseudomonas fluorescens, and by a Corynebacterium, grown on ammonium acetate. Biochemical Journal. 1958; 68(3):535-542. [PubMed: 13522656] 
Kuder T, Wilson JT, Kaiser P, Kolhatkar R, Philp P, Allen J. Enrichment of stable carbon and hydrogen isotopes during anaerobic biodegradation of MTBE: Microcosm and field evidence. Environmental Science and Technology. 2005; 39(1):213-220. [PubMed: 15667097]

Kukor JJ, Olsen RH. Molecular cloning, characterization, and regulation of a Pseudomonas pickettii PKO1 gene encoding phenol hydroxylase and expression of the gene in Pseudomonas aeruginosa PAO1c. Journal of Bacteriology. 1990; 172(8):4624-4630. [PubMed: 2115872]

Landmeyer JE, Chapelle FH, Bradley PM, Pankow JF, Church CD, Tratnyek PG. Fate of MTBE relative to benzene in a gasoline-contaminated aquifer (1993-98). Ground Water Monitoring \& Remediation. 1998; 18(4):93-102.

Lessie TG, Phibbs PV Jr. Alternative pathways of carbohydrate utilization in pseudomonads. Annual Review of Microbiology. 1984; 38:359-88.

Loper JE, Hassan KA, Mavrodi DV, Davis EW 2nd, Lim CK, Shaffer BT, Elbourne LD, Stockwell VO, Hartney SL, Breakwell K, Henkels MD, Tetu SG, Rangel LI, Kidarsa TA, Wilson NL, van de Mortel JE, Song C, Blumhagen R, Radune D, Hostetler JB, Brinkac LM, Durkin AS, Kluepfel DA, Wechter WP, Anderson AJ, Kim YC, Pierson LS 3rd, Pierson EA, Lindow SE, Kobayashi DY, Raaijmakers JM, Weller DM, Thomashow LS, Allen AE, Paulsen IT. Comparative genomics of plant-associated Pseudomonas spp.: Insights into diversity and inheritance of traits involved in multitrophic interactions. PLoS Genetics. 2012; 8(7):e1002784. [PubMed: 22792073]

Mackay D, de Sieyes N, Einarson M, Feris K, Pappas A, Wood I, Jacobson L, Justice L, Noske M, Wilson J, Adair C, Scow K. Impact of ethanol on the natural attenuation of MTBE in a normally sulfate-reducing aquifer. Environmental Science and Technology. 2007; 41(6):2015-2021. [PubMed: 17410799]

Mackay DM, de Sieyes NR, Einarson MD, Feris KP, Pappas AA, Wood IA, Jacobson L, Justice LG, Noske MN, Scow KM, Wilson JT. Impact of ethanol on the natural attenuation of benzene, toluene, and o-xylene in a normally sulfate-reducing aquifer. Environmental Science and Technology. 2006; 40(19):6123-6130. [PubMed: 17051810]

Madsen EL. The use of stable isotope probing techniques in bioreactor and field studies on bioremediation. Current Opinion in Biotechnology. 2006; 17(1):92-97. [PubMed: 16378724]

Mormile MR, Liu S, Suflita JM. Anaerobic biodegradation of gasoline oxygenates: Extrapolation of information to multiple sites and redox conditions. Environmental Science and Technology. 1994; 28(9):1727-1732. [PubMed: 22176376]

Müller RH, Rohwerder T, Harms H. Degradation of fuel oxygenates and their main intermediates by Aquincola tertiaricarbonis L108. Microbiology. 2008; 154(5):1414-1421. [PubMed: 18451050]

Naidu D, Ragsdale SW. Characterization of a three-component vanillate o-demethylase from Moorella thermoacetica. Journal of Bacteriology. 2001; 183(11):3276-3281. [PubMed: 11344134]

Neufeld JD, Vohra J, Dumont MG, Lueders T, Manefield M, Friedrich MW, Murrell JC. DNA stableisotope probing. Nature Protocols. 2007a; 2(4):860-866.

Neufeld JD, Wagner M, Murrell JC. Who eats what, where and when? Isotope-labelling experiments are coming of age. ISME Journal. 2007b; 1(2):103-110. [PubMed: 18043620]

Nevin KP, Lovley DR. Mechanisms for accessing insoluble Fe(III) oxide during dissimilatory Fe(III) reduction by Geothrix fermentans. Applied and Environmental Microbiology. 2002; 68(5):22942299. [PubMed: 11976100]

North KP, Mackay DM, Annable MD, Sublette KL, Davis G, Holland RB, Petersen D, Scow KM. An ex situ evaluation of TBA- and MTBE-baited bio-traps. Water Research. 2012; 46(12):3879-3888. [PubMed: 22621895]

Okeke BC, Frankenberger WT Jr. Biodegradation of methyl tertiary butyl ether (MTBE) by a bacterial enrichment consortia and its monoculture isolates. Microbiological Research. 2003; 158(2):99_ 106. [PubMed: 12906382]

Pruden A, Suidan MT, Venosa AD, Wilson GJ. Biodegradation of methyl tert-butyl ether under various substrate conditions. Environmental Science and Technology. 2001; 35(21):4235-4241. [PubMed: 11718336]

Radajewski S, McDonald IR, Murrell JC. Stable-isotope probing of nucleic acids: A window to the function of uncultured microorganisms. Current Opinion in Biotechnology. 2003; 14(3):296-302. [PubMed: 12849783] 
Radajewski S, Ineson P, Parekh NR, Murrell JC. Stable-isotope probing as a tool in microbial ecology. Nature. 2000; 403(6770):646-649. [PubMed: 10688198]

Rasa E, Chapman SW, Bekins BA, Fogg GE, Scow KM, Mackay DM. Role of back diffusion and biodegradation reactions in sustaining an MTBE/TBA plume in alluvial media. Journal of Contaminant Hydrology. 2011; 126(3-4):235-247. [PubMed: 22115089]

Raynal M, Crimi B, Pruden A. Enrichment and characterization of MTBE-degrading cultures under iron and sulfate reducing conditions. Canadian Journal of Civil Engineering. 2010; 37(4):522-534.

Saitou N, Nei M. The neighbor-joining method: A new method for reconstructing phylogenetic trees. Molecular Biology and Evolution. 1987; 4:406-425. [PubMed: 3447015]

Salanitro JP, Diaz LA, Williams MP, Wisniewski HL. Isolation of a bacterial culture that degrades methyl t-butyl ether. Applied and Environmental Microbiology. 1994; 60(7):2593-2596. [PubMed: 16349335]

Schloss PD, Handelsman J. Introducing DOTUR a computer program for defining operational taxonomic units and estimating species richness. Applied and Environmental Microbiology. 2005; 71(3):1501-1506. [PubMed: 15746353]

Schmidt TC, Schirmer M, Weiß H, Haderlein SB. Microbial degradation of methyl tert-butyl ether and tert-butyl alcohol in the subsurface. Journal of Contaminant Hydrology. 2004; 70(3-4):173-203. [PubMed: 15134874]

Smith CA, Hyman MR. Oxidation of methyl tert-butyl ether by alkane hydroxylase in dicyclopropylketone-induced and n-octane-grown Pseudomonas putida GPo1. Applied and Environmental Microbiology. 2004; 70(8):4544-4550. [PubMed: 15294784]

Somsamak P, Richnow HH, Häggblom MM. Carbon istope fractionation during anaerobic degradation of methyl tert-butyl ether under sulfate-reducing and methanogenic conditions. Applied and Environmental Microbiology. 2006; 72(2):1157-1163. [PubMed: 16461662]

Somsamak P, Cowan RM, Häggblom MM. Anaerobic biotransformation of fuel oxygenates under sulfate-reducing conditions. FEMS Microbiology Ecology. 2001; 37(3):259-264.

Steffan RJ, McClay K, Vainberg S, Condee CW, Zhang D. Biodegradation of the gasoline oxygenates methyl tert-butyl ether, ethyl tert-butyl ether, and tert-amyl methyl ether by propane-oxidizing bacteria. Applied and Environmental Microbiology. 1997; 63(11):4216-4222. [PubMed: 9361407]

Suflita JM, Mormile MR. Anaerobic biodegradation of known and potential gasoline oxygenates in the terrestrial subsurface. Environmental Science and Technology. 1993; 27(5):976-978.

Sun W, Sun X, Cupples AM. Anaerobic methyl tert-butyl ether-degrading microorganisms identified in wastewater treatment plant samples by stable isotope probing. Applied and Environmental Microbiology. 2012; 78(8):2973-2980. [PubMed: 22327600]

Thompson JD, Gibson TJ, Plewniak F, Jeanmongin F, Higgins DG. The ClustalX windows interface: Flexible strategies for multiple sequence alignment aided by quality analysis tools. Nucleic Acids Research. 1997; 25:4876-4882. [PubMed: 9396791]

Wang Q, Garrity GM, Tiedje JM, Cole JR. Naïve bayesian classifier for rapid assignment of rRNA sequences into the new bacterial taxonomy. Applied and Environmental Microbiology. 2007; 73(16):5261-5267. [PubMed: 17586664]

Weber H, Kulbe K, Chmiel H, Trösch W. Microbial acetate conversion to methane: Kinetics, yields and pathways in a two-step digestion process. Applied Microbiology and Biotechnology. 1984; 19(4):224-228.

Wei N, Finneran K. Microbial community analyses of three distinct, liquid cultures that degrade methyl tert-butyl ether using anaerobic metabolism. Biodegradation. 2009; 20(5):695-707. [PubMed: 19340592]

White GF, Russell NJ, Tidswell EC. Bacterial scission of ether bonds. Microbiological Reviews. 1996; 60(1):216-232. [PubMed: 8852901]

Wilson JT, Adair C, Kaiser PM, Kolhatkar R. Anaerobic biodegradation of MTBE at a gasoline spill site. Ground Water Monitoring \& Remediation. 2005; 25(3):103-115.

Wilson GJ, Richter AP, Suidan MT, Venosa AD. Aerobic biodegradation of gasoline oxygenates MTBE and TBA. Water Science and Technology. 2001; 43(2):277-284. [PubMed: 11380191] 
Wilson, JT.; Cho, JS.; Wilson, BH.; Vardy, J. Natural Attenuation of MTBE in the Subsurface Under Methanogenic Conditions. Washington, D.C.: Environmental Protection Agency, Office of Research and Development; 2000.

Wu X, Monchy S, Taghavi S, Zhu W, Ramos J, van der Lelie D. Comparative genomics and functional analysis of niche-specific adaptation in Pseudomonas putida. FEMS Microbiology Reviews. 2011; 35(2):299-323. [PubMed: 20796030]

Youngster, L. Microbiology and Molecular Genetics. New Brunswick, New Jersey: Rutgers University; 2009. Microbial degradation of the fuel oxygenate methyl tert-butyl ether (MTBE).

Youngster LKG, Kerkhof LJ, Häggblom MM. Community characterization of anaerobic methyl tertbutyl ether (MTBE)-degrading enrichment cultures. FEMS Microbiology Ecology. 2010; 72(2): 279-288. [PubMed: 20180853]

Youngster LG, Somsamak P, Häggblom M. Effects of co-substrates and inhibitors on the anaerobic Odemethylation of methyl tert-butyl ether (MTBE). Applied Microbiology and Biotechnology. 2008; 80(6):1113-1120. [PubMed: 18797864]

Zein MM, Suidan MT, Venosa AD. MTBE biodegradation in a gravity flow, high-biomass retaining bioreactor). Environmental Science and Technology. 2004; 38(12):3449-3456. [PubMed: 15260347] 


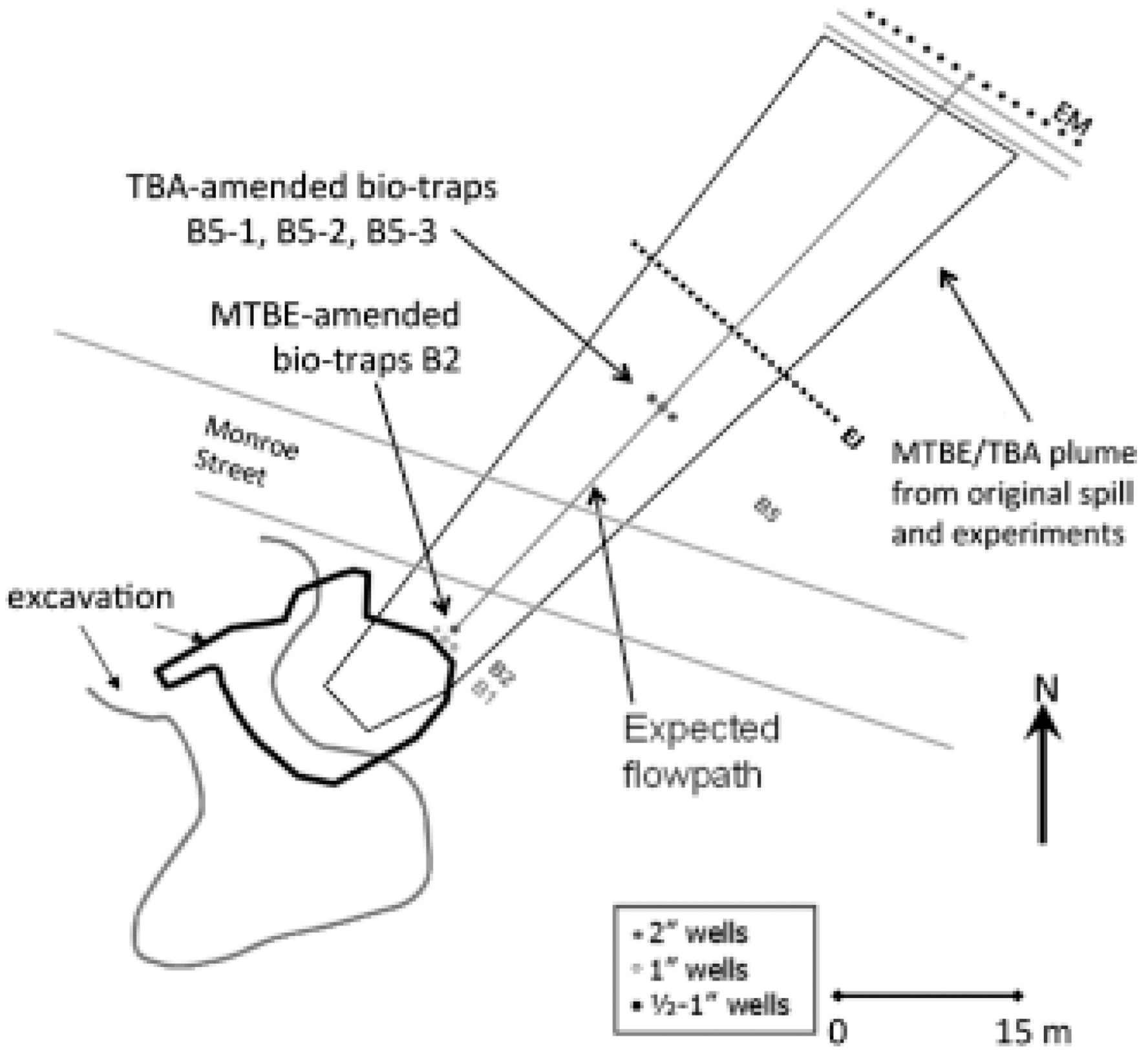

Figure 1.

Site 60 map, Bio-traps amended with ${ }^{13} \mathrm{C}_{4}$-TBA were deployed in the three wells in the B5 transect, and ${ }^{13} \mathrm{C}_{5}$-MTBE and ${ }^{13} \mathrm{C}_{1}$-MTBE bio-traps were deployed in well $\mathrm{B} 2$. The line extending from the excavation area to the EM transect indicates the best estimate of the groundwater flow direction based on TBA plume monitoring. 


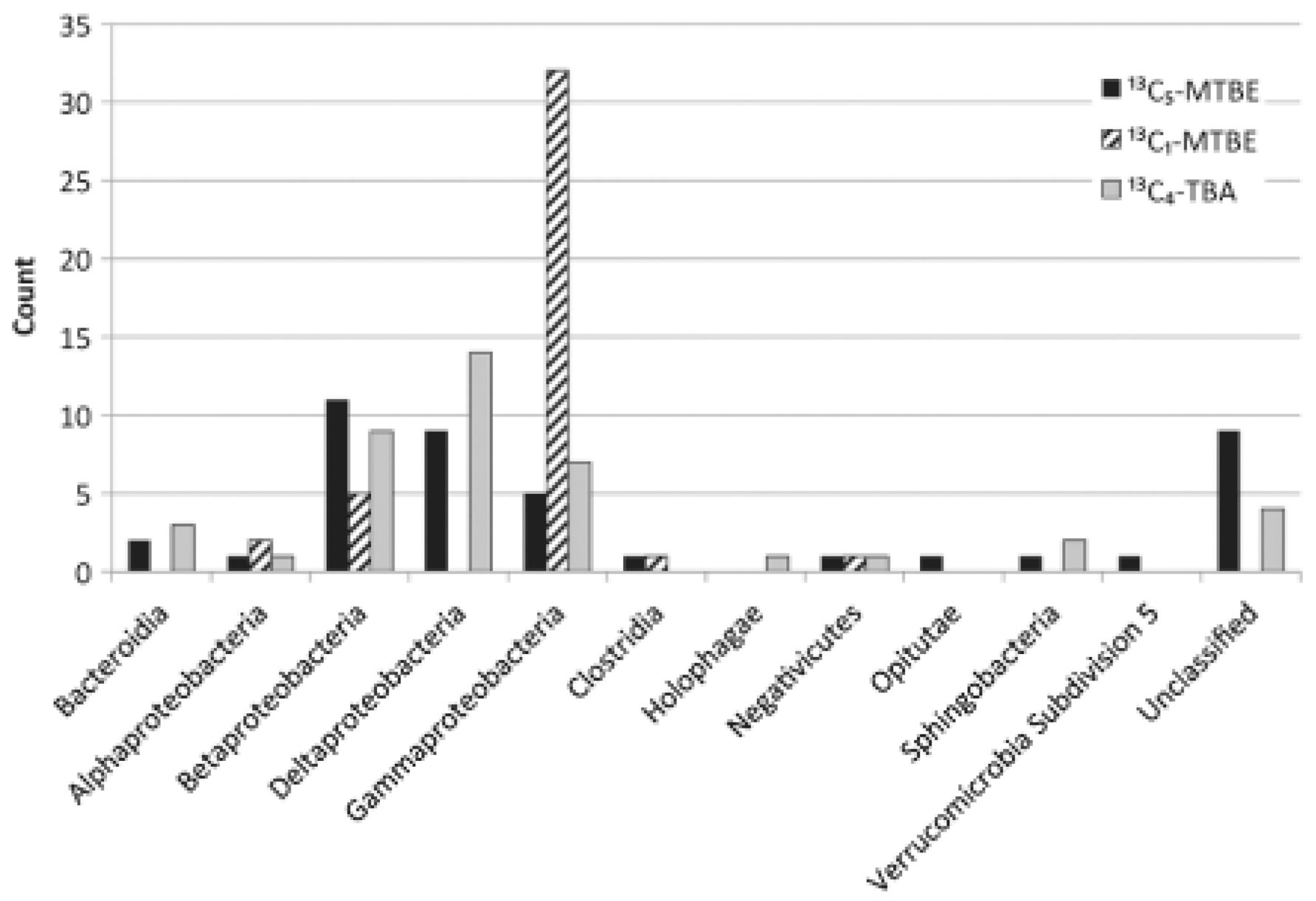

Figure 2.

Higher-level affiliations of ${ }^{13} \mathrm{C}$-labeled DNA. 


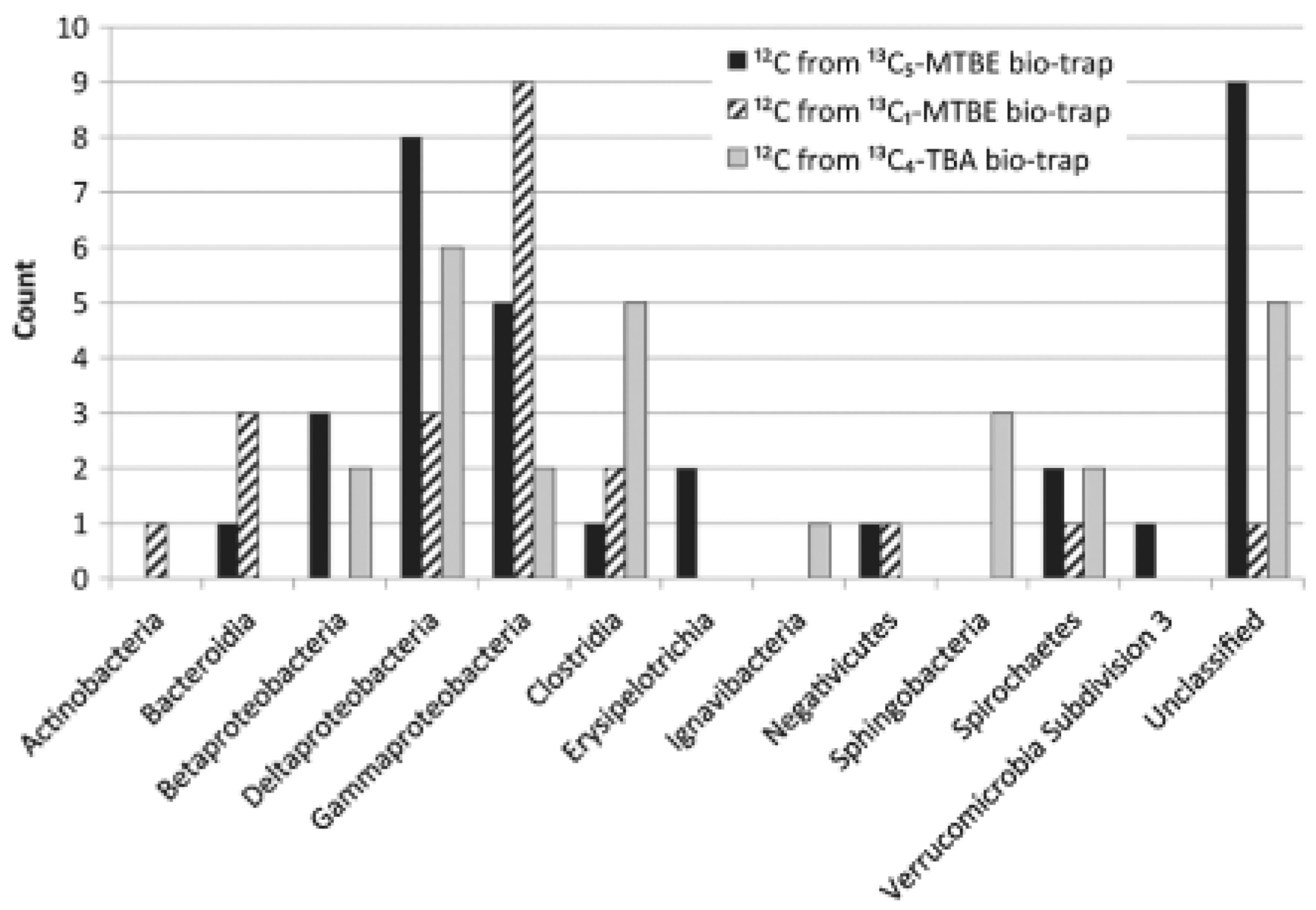

Figure 3.

Higher-level affiliations of ${ }^{12} \mathrm{C}$-labeled DNA. 


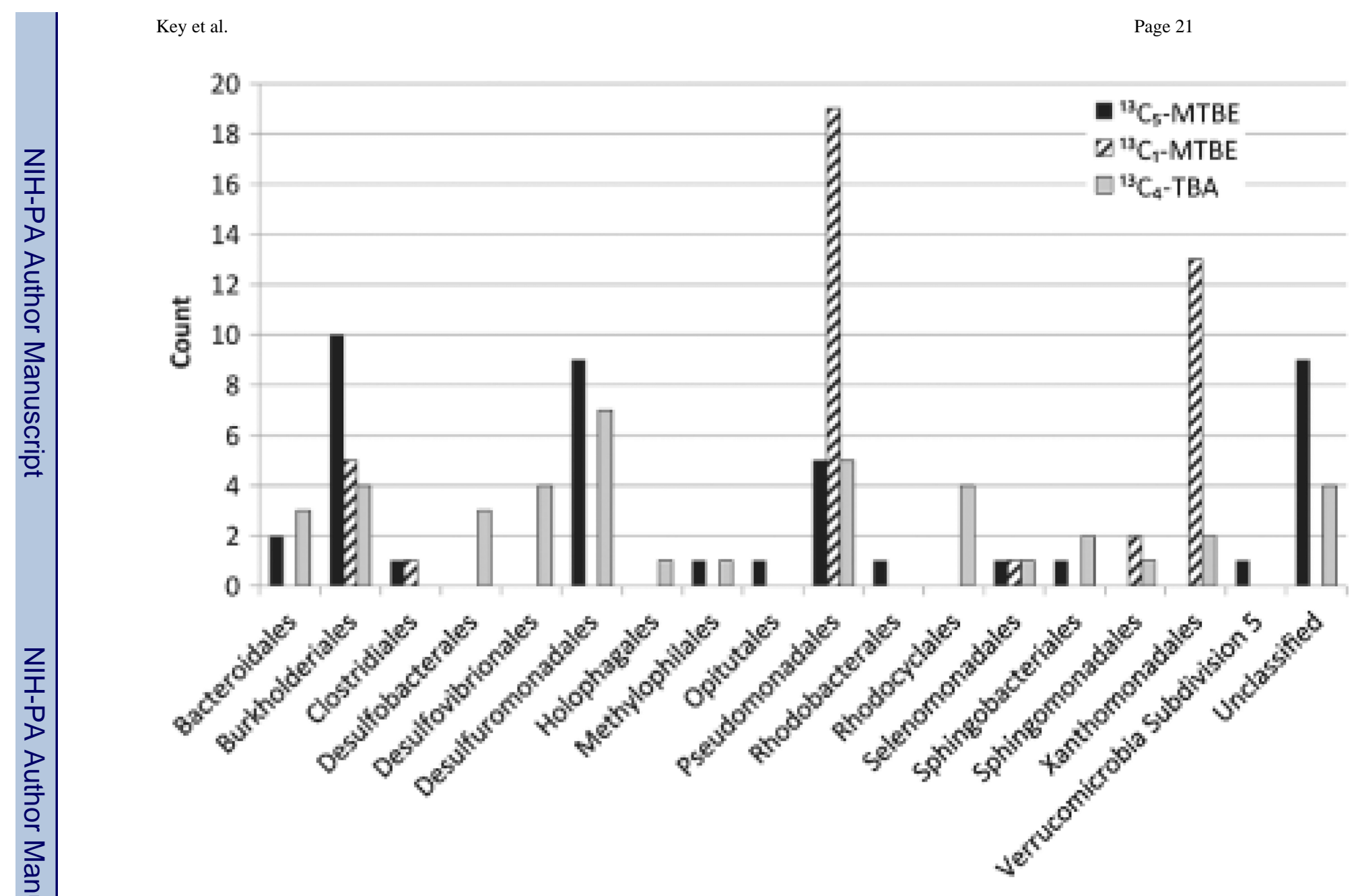

Figure 4.

Order-level affiliations of ${ }^{13} \mathrm{C}$-labeled DNA. 

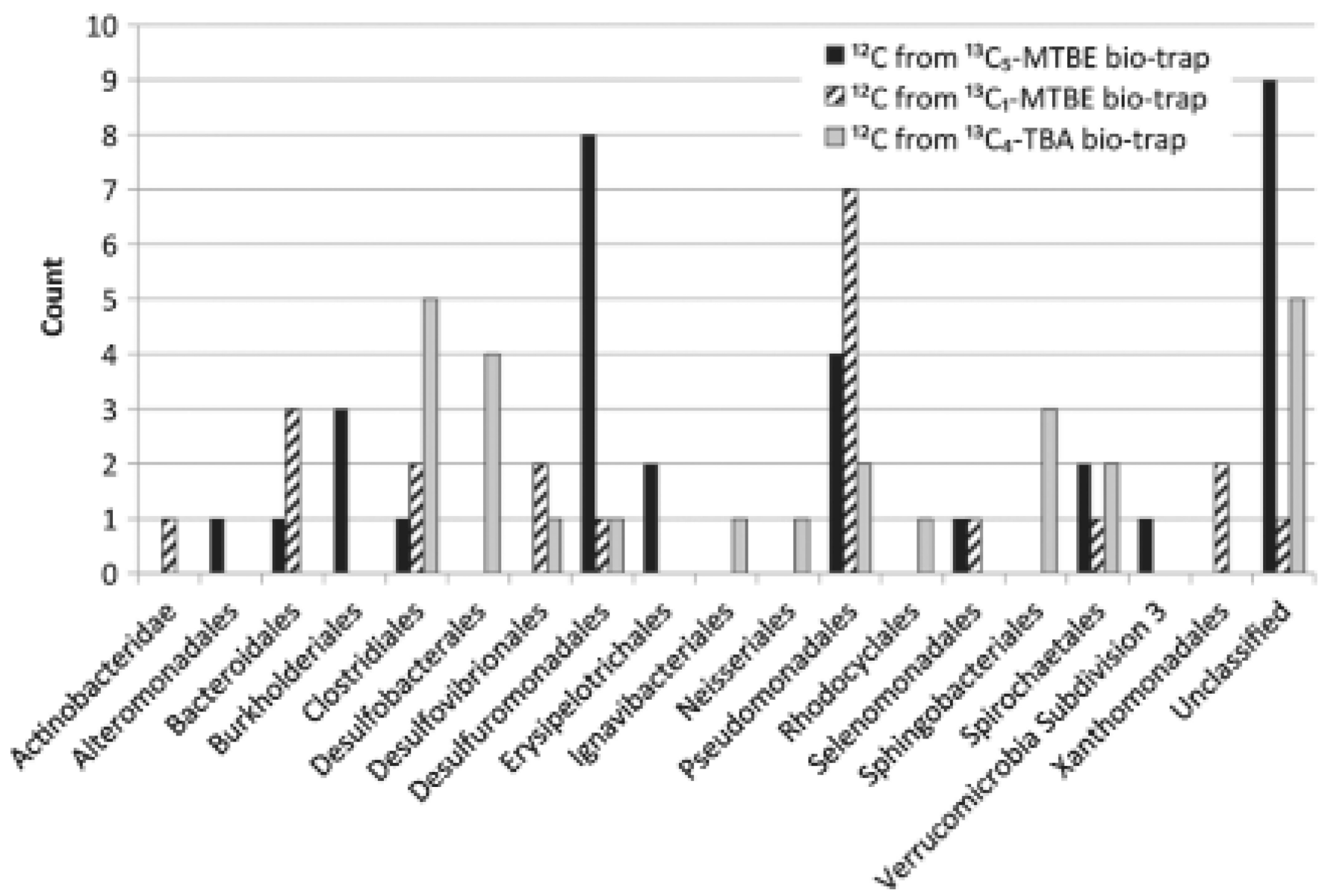

Figure 5.

Order-level affiliations of ${ }^{12} \mathrm{C}$-labeled DNA. 

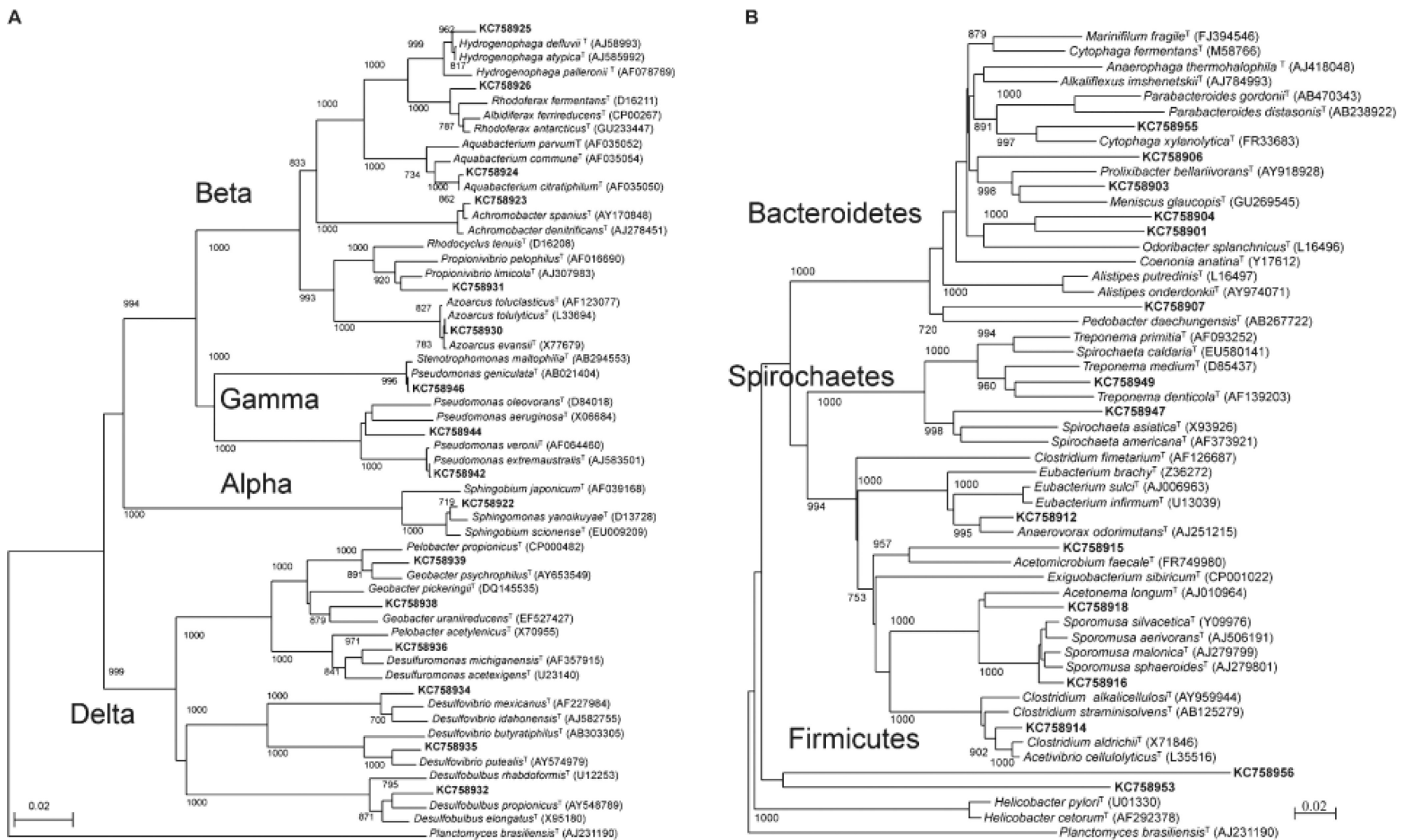

Figure 6.

Phylogenetic relationships of representative 16S rRNA gene sequences cloned from PCR amplicon products of DNA extracted from Bio-Sep beads incubated in a sulfate-reducing MTBE and TBA plume. Sequences were grouped into operational taxonomic units with $97 \%$ similarity and one sequence chosen to represent all the sequences in the operational taxonomic unit. Only operational taxonomic units representing two or more sequences were shown. See also Supporting Information. The trees were constructed from nucleotide gene sequences using the neighbor-joining algorithm. One thousand bootstrap replications were performed; only values 700 and greater are shown. Approximately 1320 bp. Bar: 0.02 nucleotide substitutions per nucleotide. (A) Representative sequences of Proteobacteria, with Planctomyces braziliensis as the outgroup sequence. Phylogenetic affiliations of representative sequences of Proteobacteria. (B) Representative sequences from all groups except Proteobacteria, withPlanctomyces and Helicobacter as the outgroup sequences. Phylogenetic affiliations of representative sequences from all groups except Proteobacteria 


\section{Table 1}

Contaminant Loss from Bio-Sep Beads

\begin{tabular}{lcccc}
\hline Monitoring Well & Chemical & Pre-Deployment (ing/bead) & Post-Incubation (mg/bead) & \% Loss \\
\hline B5-1 & $100 \%{ }^{13} \mathrm{C}_{4}$-TBA & $1.03 \pm 0.06$ & $0.29 \pm 0.01$ & $72 \%$ \\
B5-2a & $100 \%{ }^{13} \mathrm{C}_{4}$-TBA & $1.03 \pm 0.06$ & $0.25 \pm 0.007$ & $76 \%$ \\
B5-2b & $100 \%{ }^{13} \mathrm{C}_{4}$-TBA & $1.03 \pm 0.06$ & $0.04 \pm 0.001$ & $96 \%$ \\
B5-3 & $100 \%{ }^{13} \mathrm{C}_{4}$-TBA & $1.03 \pm 0.06$ & $0.25 \pm 0.018$ & $76 \%$ \\
B2a & $100 \%{ }^{13} \mathrm{C}_{5}$-MTBE & $0.46 \pm 0.025$ & $0.31 \pm 0.03$ & $33 \%$ \\
B2b & $100 \%{ }^{13} \mathrm{C}_{5}$-MTBE & $0.46 \pm 0.025$ & $0.28 \pm 0.016$ & $39 \%$ \\
B2a & $100 \%{ }^{13} \mathrm{C}_{1}$-MTBE & $0.59 \pm 0.026$ & $0.15 \pm 0.004$ & $75 \%$ \\
B2b & $100 \%{ }^{13} \mathrm{C}_{1}$-MTBE & $0.59 \pm 0.026$ & $0.15 \pm 0.004$ & $75 \%$ \\
\hline
\end{tabular}


Table 2

Sequence Analysis Summary

\begin{tabular}{lccc}
\hline Clone Library & \# Sequences & \# Operational Taxonomic Units $\boldsymbol{a}$ & \% Coverage $\boldsymbol{b}^{\boldsymbol{b}}$ \\
\hline${ }^{13} \mathrm{C}_{1}$-MTBE & 41 & 7 & $93 \%$ \\
${ }^{13} \mathrm{C}_{5}$-MTBE & 42 & 20 & $69 \%$ \\
${ }^{13} \mathrm{C}_{4}$-TBA & 42 & 23 & $69 \%$ \\
${ }^{12} \mathrm{C}$ from ${ }^{13} \mathrm{C}_{1}$-MTBE bo-trap & 21 & 10 & $76 \%$ \\
${ }^{12} \mathrm{C}$ from ${ }^{13} \mathrm{C}_{5}$-MTBE bio-trap & 33 & 20 & $58 \%$ \\
${ }^{12} \mathrm{C}$-TBA & 26 & 14 & $77 \%$ \\
\hline${ }_{\text {Based on } 97 \% \text { sequence similarity }}$ & & & \\
$b_{\text {Good's method (Good 1953). }}$ & &
\end{tabular}


Table 3

Number of Operational Taxonomic Units Shared Between Clone Libraries

\begin{tabular}{llcc}
\hline Clone Libraries Compared & & $\begin{array}{c}\text { \# Operational Taxonomic Units } \\
\text { Shared }\end{array}$ & $\begin{array}{c}\text { \# Operational Taxonomic Units } \\
\text { Total }\end{array}$ \\
\hline${ }^{13} \mathrm{C}_{5}$-MTBE & ${ }^{13} \mathrm{C}_{1}$-MTBE & 1 & 26 \\
${ }^{13} \mathrm{C}_{5}$-MTBE & ${ }^{13} \mathrm{C}_{4}$-TBA & 7 & 36 \\
${ }^{13} \mathrm{C}_{1}$-MTBE & ${ }^{13} \mathrm{C}_{4}$-TBA & 3 & 27 \\
${ }^{12} \mathrm{C}$ from ${ }^{13} \mathrm{C}_{5}$-MTBE bio-trap & ${ }^{12} \mathrm{C}$ from ${ }^{13} \mathrm{C}_{1}$-MTBE bio-trap & 2 & 28 \\
${ }^{12} \mathrm{C}$ from ${ }^{13} \mathrm{C}_{5}$-MTBE bio-trap & ${ }^{12} \mathrm{C}-\mathrm{TBA}$ & 1 & 33 \\
${ }^{12} \mathrm{C}$ from ${ }^{13} \mathrm{C}_{1}$-MTBE bio-trap & ${ }^{12} \mathrm{C}-\mathrm{TBA}$ & 1 & 23 \\
${ }^{13} \mathrm{C}_{5}$-MTBE & ${ }^{12} \mathrm{C}$ from ${ }^{13} \mathrm{C}_{5}$-MTBE bio-trap & 8 & 32 \\
${ }^{13} \mathrm{C}_{1}$-MTBE & ${ }^{12} \mathrm{C}$ from ${ }^{13} \mathrm{C}_{1}$-MTBE bio-trap & 3 & 14 \\
${ }^{13} \mathrm{C}_{4}$-TBA & ${ }^{12} \mathrm{C}-\mathrm{TBA}$ & 7 & 30 \\
\hline
\end{tabular}




\section{Table 4}

Ribasomal Database Project Classifier Summary ${ }^{a}$

\begin{tabular}{|c|c|c|c|}
\hline Clone Library & $\begin{array}{l}\text { Most Abundant Class } \\
(\%)\end{array}$ & $\begin{array}{l}\text { Most Abundant Order } \\
(\%)\end{array}$ & Most Abundant Genus (\%) \\
\hline${ }^{13} \mathrm{C}_{5}$-MTBE & Betaprcteobacteria (26\%) & Burkholderiales (24\%) & Geobacter (19\%) \\
\hline${ }^{13} \mathrm{C}_{1}$-MTBE & Gammaproteobacteria $(78 \%)$ & Pseudomonadales (46\%) & Pseudomonas (46\%) \\
\hline${ }^{13} \mathrm{C}_{4}$-TBA & Deltaproteobacteria (33\%) & Desulfuromonadales (17\%) & $\begin{array}{l}\text { Desuifovibrio }(10 \%), \text { Geobacter }(10 \%) \text {, } \\
\text { Pseudomonas }(10 \%)\end{array}$ \\
\hline${ }^{12} \mathrm{C}$ from ${ }^{13} \mathrm{C}_{5}$-MTBE bio-trap & Deltaproteobacteria (24\%) & Desutfuromonadales (24\%) & Geobacter $(21 \%)$ \\
\hline${ }^{12} \mathrm{C}$ from ${ }^{13} \mathrm{C}_{1}-\mathrm{MTBE}$ bio-trap & Gammaproteobacteria (43\%) & Pseudomonadales (33\%) & Pseudomonas $(33 \%)$ \\
\hline${ }^{12} \mathrm{C}-\mathrm{TBA}$ & Deltaproteobacteria (23\%) & Clostridiales $(19 \%)$ & Desutfobutbus (15\%), Unclassified (15\%) \\
\hline Overall & Gammaproteobacteria (29\%) & Pseudomonadales (20\%) & Pseudomonas $(20 \%)$ \\
\hline
\end{tabular}

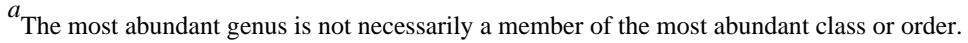

